\title{
Toxicity for Aquatic Organisms of Antiretroviral Tenofovir Disoproxil
}

\author{
S. R. Silva1, F. A. R. Barbosa' ${ }^{2}$, M. P. G. Mol' ${ }^{3}$, S. M. S. Magalhães ${ }^{1}$ \\ ${ }^{1}$ Department of Social Pharmacy, Pharmacy School, Federal University of Minas Gerais, Belo Horizonte, Minas Gerais, Brazil \\ ${ }^{2}$ Department of General Biology, Institute of Biological Sciences, Federal University of Minas Gerais, Belo Horizonte, \\ Minas Gerais, Brazil \\ ${ }^{3}$ Research and Development Board, Ezequiel Dias Foundation, Belo Horizonte, Minas Gerais, Brazil \\ Email: srssandrars@gmail.com
}

How to cite this paper: Silva, S.R., Barbosa, F.A.R., Mol, M.P.G. and Magalhães, S.M.S. (2019) Toxicity for Aquatic Organisms of Antiretroviral Tenofovir Disoproxil. Journal of Environmental Protection, 10, 1565-1577. https://doi.org/10.4236/jep.2019.1012093

Received: October 24, 2019

Accepted: December 3, 2019

Published: December 6, 2019

Copyright (c) 2019 by author(s) and Scientific Research Publishing Inc. This work is licensed under the Creative Commons Attribution International License (CC BY 4.0).

http://creativecommons.org/licenses/by/4.0/

\section{(c) (i) Open Access}

\begin{abstract}
Tenofovir disoproxil fumarate is a prodrug, i.e. inative substance converted in vivo, after absorption to the active form de-esterified tenofovir, which acts as an inhibitor of viral reverse transcriptase. To better understand the toxic effects of these drugs in the environment, three organisms were tested, the effective concentration $\left(\mathrm{EC}_{50}\right)$ and inhibitory concentration $\left(\mathrm{IC}_{50}\right)$ of tenofovir disoproxil that resulted in 50\% growth inhibition of Microcystis novacekii, 50\% immobilization of Artemia salina, and 50\% loss of bioluminescence of Aliivibrio fischeri were evaluated. The $\mathrm{EC}_{50}$ value after $96 \mathrm{~h}$ of treatment for the cyanobacterium was $161.01(156.81-165.21) \mathrm{mg} \cdot \mathrm{L}^{-1}$; the $\mathrm{IC}_{50}$ value for $A$. salina after $24 \mathrm{~h}$ of treatment was $111.82(103.18-120.45) \mathrm{mg} \cdot \mathrm{L}^{-1}$; and the $\mathrm{IC}_{50}$ at $15 \mathrm{~min}$ for $A$. fischeri was $14.83(13.87-15.79) \mathrm{mg} \cdot \mathrm{L}^{-1}$. The test organism most sensitive to the drug was $A$. fischeri, indicating the importance of using representative models at different trophic levels to assess the potential risk of drugs for environmental toxicity. These results highlight the possible effect of tenofovir disoproxil on decomposer organisms, which may contribute to the environmental persistence of this drug.
\end{abstract}

\section{Keywords}

Emerging Contaminant, Aliivibrio fischeri, Artemia salina, Microcystis novacekii

\section{Introduction}

Drug residues have been reported in several environmental systems and are considered emerging contaminants [1] [2]. In aquatic environments, these contaminants, especially more stable and persistent substances, may present a risk to 
aquatic species [3]. A number of studies have indicated insufficient drug removal at water and effluent treatment stations [4] [5] [6], which highlights the importance of assessing the toxic effects of drug residues on aquatic species.

Tenofovir disoproxil fumarate (TDF) is an antiretroviral belonging to the class of nucleotide analogs used in the treatment of HIV/AIDS and viral hepatitis. TDF is a prodrug, i.e. inative substance hydrolyzed in vivo to release the active portion of the molecule, tenofovir (TFV) (Figure 1). The prodrug is used to enhance tenofovir liposolubility and permeation across the intestinal cells.

After absorption by human organisms, TDF is de-esterified and after phosphorylation, the TFV molecule acts as an inhibitor of the viral enzyme reverse transcriptase by competing with its natural substrate, adenosine 5 '-monophosphate, thus disrupting DNA synthesis and, consequently, viral replication [7]. According to Kim et al. [8], after human use of this drug, up to $80 \%$ of the TFV is eliminated in unmodified urine, indicating its potential entry into domestic and hospital sewage in its active form. TFV is a very stable molecule [9], leading to concerns about the effects of this drug on aquatic species.

Residues of more than 20 antiretrovirals drugs have been detected in various environmental compartments such as wastewater effluent, river and lakewater, hospital effluent, groundwater, drink water, landfill leachates, at varying concentrations depending on the antiviral drug [10] [11] [12]. The tenofovir has been described at low concentrations (145 - $\left.243 \mathrm{ng} \cdot \mathrm{L}^{-1}\right)$ in surface waters from South Africa [13]. A study by Al-Rajab et al. [9] in London has shown that tenofovir is persistent in soils with no evidence of transformation products or microbial based degradation. The effects of TFV on DNA synthesis and its possible interference with metabolic pathways affecting viability and cell growth of other species are unknown, and its environmental impact needs to be investigated.

Although the importance of understanding the toxicity of chemical substances for aquatic species has been recognized, there is still limited information on the effects of most drugs on the environment [14]. Several factors are associated with the toxicity of drugs in the environment, including the selectivity of the drug for the target system, its interactions with other substances in the environment and its physicochemical characteristics, as well as the intrinsic sensitivity of

Tenofovir disoproxil<smiles>CC(C)OC(=O)OCOP(=O)(COC(C)Cn1cnc2c(N)ncnc21)OCOC(=O)OC(C)C</smiles>

Tenofovir

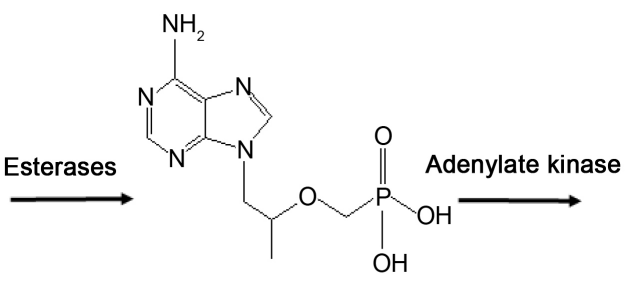

Tenofovir diphosphate

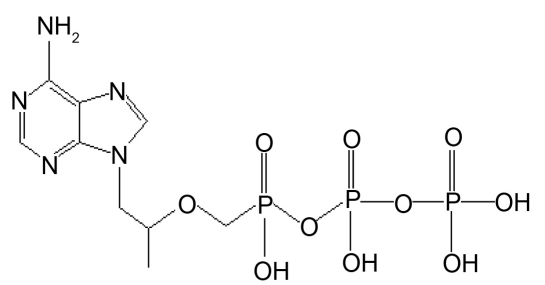

Figure 1. Metabolism of tenofovir disoproxil. 
the test system. Thus, environmental toxicity can be assessed by applying tests using different test organisms belonging to at least two trophic levels [15].

Among the most commonly used test organisms are cyanobacteria. Cyanobacteria are widely studied because of their rapid response to environmental modifications, survival in polluted aquatic environments, and dominance among other species [16]. The cyanobacterium Microcystis novacekii is a ubiquitous unicellular photosynthetic prokaryote [17]. According to Bicudo and Menezes (2006) [18], Microcystis is the cyanobacterial genus with the widest distribution in Brazil, which justifies the use of species of this genus in toxicity tests.

Artemia salina is a widespread microcrustacean that forms a link between planktonic communities and higher levels of food chains. A. salina is considered an important model for the evaluation of toxicity and possible bioaccumulation of xenobiotics in the trophic chain [19] [20]. A third model, the bioluminesce test using the bacterium Aliivibrio fischeri, as test organisms often used in environmental toxicity studies. A. fischeri is a gram-negative heterotrophic organism with widespread distribution. It is a saprophytic, free-living bacterium that uses dissolved or particulate organic matter from marine environments as a carbon source [21]. A. fischeri is characterized by light emission under favourable environmental conditions. A. fischeri is a very sensitive model for the evaluation of chemical toxicity because of its rapid response to environmental variations [15].

The objective of this study was to determine the inhibitors concentration of TDF for test organisms: $M$. novacekii (cyanobacteria), A. salina (microcrustaceans) and $A$. fischeri (bacteria).

\section{Materials and Methods}

\subsection{Chemicals Tests}

The TDF sample used in this study were white dry powder, produced by Nortec Química, Brazil, (lot 507034) purity $\geq 99 \%$, identified and certified by the Quality Control Laboratory of the Ezequiel Dias Foundation (FUNED). All solvents and reagents used were of analytical grade.

\subsection{Test Organisms}

The species M. novacekii was isolated at Rio Doce State Park and then identified and maintained in culture by the Laboratory of Limnology, Ecotoxicology and Aquatic Ecology, Institute of Biological Sciences, Federal University of Minas Gerais (LIMNEA/ICB/UFMG), Brazil. A. salina hatching eggs (Maramar, lot 07) were purchased from a retail store in Belo Horizonte, Brazil. A freeze-dried $A$. fischeri stock was purchased from Biolux ${ }^{\oplus}$.

\subsection{M. novacekii Growth Inhibition Tests}

M. novacekii cultures were maintained in germination chambers at $23.0^{\circ} \mathrm{C} \pm 2^{\circ} \mathrm{C}$ with a $12 \mathrm{~h}$ light $/ 12 \mathrm{~h}$ dark photoperiod under light intensity (radiance of $40-50$ $\mu \mathrm{mol} \cdot \mathrm{m}^{-2} \cdot \mathrm{s}^{-1}$ ) [22]. The medium used for the cultivation and in the M. novacekii 
assays was ASM1 [23]. In total, $750 \mathrm{mg} \cdot \mathrm{L}^{-1}$ of 3-(N-morpholino)

propanesulphonic acid (MOPS), $\mathrm{pKa}=7.2$ at $25^{\circ} \mathrm{C}$, was added to freshly prepared and sterilized medium. The $\mathrm{pH}$ was adjusted to 7.0 with either $0.1 \mathrm{~mol} \cdot \mathrm{L}^{-1}$ $\mathrm{HCl}$ or $\mathrm{NaOH}$ solution. The optical densities of the cultures were determined by visible spectrometry at $680 \mathrm{~nm}\left(\mathrm{OD}_{680}\right)$ [24], and the correlation between the cell density (number of cells $\cdot \mathrm{mL}^{-1}$ ) and the absorbance was obtained by linear regression analysis.

For the M. novacekii growth inhibition tests, the OECD 201 protocol (2006) [25] was used, with some modifications. To cultures of $M$. novacekii with a cell density of $10^{6}$ cells $\cdot \mathrm{mL}^{-1}$, TDF was added to obtain nominal concentrations of $40.00,56.00,78.40,109.76,153.66,215.12$, and $300.00 \mathrm{mg} \cdot \mathrm{L}^{-1}$. This concentration range was defined from preliminary tests. The Erlenmeyer flasks were incubated in triplicate at $25.0^{\circ} \mathrm{C} \pm 2.0^{\circ} \mathrm{C}$ with a $12 \mathrm{~h}$ photoperiod and with constant stirring. Cell growth was monitored by $\mathrm{OD}_{680}$ of the culture, measured at the initial time $\left(\mathrm{T}_{0}\right)$ and then every $24 \mathrm{~h}$. The $\mathrm{pH}$ was maintained in the range of 6.0 to 7.0 with MOPS buffer. Based on the growth curves, the mean growth rates were calculated, and the percentage growth inhibition curves were constructed as a function of the concentrations of TDF and TFV.

The growth rate coefficient $(\mu)$ for each culture (tests and controls) was calculated at $96 \mathrm{~h}$ according to the following equation:

$$
\mu=\left(\ln X_{1}-\ln X_{0}\right) /\left(t_{1}-t_{0}\right)
$$

where $X_{0}$ and $X_{1}$ are the number of cells (optical density) at 0 and $96 \mathrm{~h}$, respectively; $t_{0}$ denotes 0 days; $t_{1}$ denotes the fourth day; and $\mu$ is the average specific growth rate from the period $\left(\right.$ day $\left.^{-1}\right)$.

\subsection{A. salina Acute Immobilization Test}

A method adapted from Meyer et al. (1982) [26] was used in the $A$. salina assay. $A$. salina eggs were incubated under illumination for $36 \mathrm{~h}$ in a $3 \%$ saline solution ( $\mathrm{pH} 8.0$ to 9.0) until the formation of nauplii (larvae). Ten larvae were separated and transferred to test tubes containing $5.00 \mathrm{~mL}$ of TDF at the following concentrations in a saline solution: $30.00,60.00,90.00,120.00,150.00$, and $180.00 \mathrm{mg} \cdot \mathrm{L}^{-1}$. The tubes were maintained under artificial light for $24 \mathrm{~h}$ when non-motile larvae were counted.

\subsection{Inhibition of Bioluminescence of $A$. fischeri}

To evaluate the inhibition of $A$. fischeri bioluminescence, the tests were performed according to ABNT NBR 15411-3 (2012) [27], the instrument used in the test $A$. fischeri was Biofix ${ }^{\oplus}$, ModeloLumi-10, Marcherey-nagel. The following nine serial dilutions of TDF in $2 \% \mathrm{NaCl}$ were used: 4.38, 8.80, 13.20, 17.60, $18.48,21.12,26.40,35.20,52.80$, and $70.40 \mathrm{mg} \cdot \mathrm{L}^{-1}$. The cultures were incubated at $15.0^{\circ} \mathrm{C}$ for $15 \mathrm{~min}$, and a $2 \% \mathrm{NaCl}$ solution was used as a negative control [28] The loss of bacterial luminescence (INH\%) due to the addition of toxic substances was calculated as follows: 


$$
\begin{gathered}
K F=I C_{t} / I C_{0} \\
\mathrm{INH} \%=100-\left[I T_{t} /\left(K F \times I T_{0}\right)\right] \times 100
\end{gathered}
$$

where $I C_{0}$ and $I T_{0}$ are the luminescence of the control and test samples at $t=0$, $I C_{T}$ and $I T_{T}$ are luminescence values for control and test samples measured after 15 min of exposure time, and $\mathrm{KF}$ is the correction factor based on the control/blank. $\mathrm{R}$ software was used to compare the intensities of the light emitted by the samples with the various dilutions of TDF and the control solution.

\subsection{Data Analysis}

The statistical dose-response regression models represent the relation between the independent variable (dose or concentration) and the dependent variable (response or effect). Log-logistic, log-normal, and Weibull models were tested using the extension package drc for the statistical software R (version 3.4.2) to estimate the best fitting function [29].

\section{Results}

The growth inhibition curves of $M$. novacekii exposed to TDF are shown in Figure 2(a). Based on the growth inhibition as a function of TDF concentrations (Figure 2(b)), the effective concentration $\left(\mathrm{EC}_{50}\right.$ ) of TDF for M. novacekii was estimated to be $161.01(156.81 ; 165.21) \mathrm{mg} \cdot \mathrm{L}^{-1}$ at $96 \mathrm{~h}$ of treatment. This value refers to the TDF concentration, however, the results can be expressed as (TFV), because TDF is a prodrug and easily and spontaneously de-esterified in biological medium [30] [31] for which the $\mathrm{IC}_{50}$ corresponded to 89.00 (86.67; 91.31) $\mathrm{mg} \cdot \mathrm{L}^{-1}$. The $\mathrm{IC}_{50}$ model for TFV was found considering the stoichiometric calculation of the molar mass (MM) of tenofovir disoproxil ( $\mathrm{MM}=519.4 \mathrm{~g} / \mathrm{mol})$ and the tenofovir $(287.2 \mathrm{~g} / \mathrm{mol})$. The TFV is considered to be the active part of the molecule and the other concentration data is available in the literature, presented in terms of TFV.

The immobility of $A$. salina nauplii was observed after $24 \mathrm{~h}$ and the inhibition of luminescence of $A$. fischeri after 15 minutes of exposure to TDF. The TDF and TFV concentrations affecting the viability of these species are shown in Table 1.

\section{Discussion}

In this study, three trophic organisms were used: a cyanobacterium (primary producer), a crustacean (primary consumer) and a bacterium (decomposer), to estimate the environmental toxicity of tenofovir disoproxil.

\subsection{Toxicity of TDF to Cyanobacterium M. novacekii}

It was found in this study that $M$. novacekii showed resistance to TDF, tolerating concentrations higher than $100.00 \mathrm{mg} \cdot \mathrm{L}^{-1}$. According to the criteria of the Globally Harmonized System of Classification and Labelling of Chemicals (GHS, 2017) [32], TDF can be considered as having low acute toxicity for this strain. 


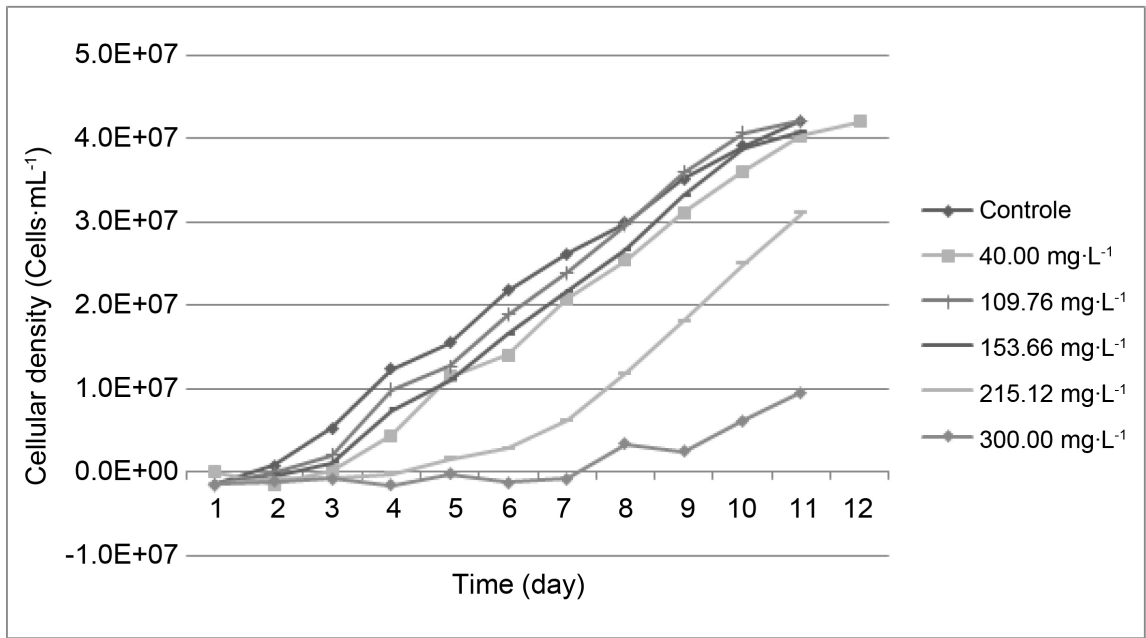

(a)

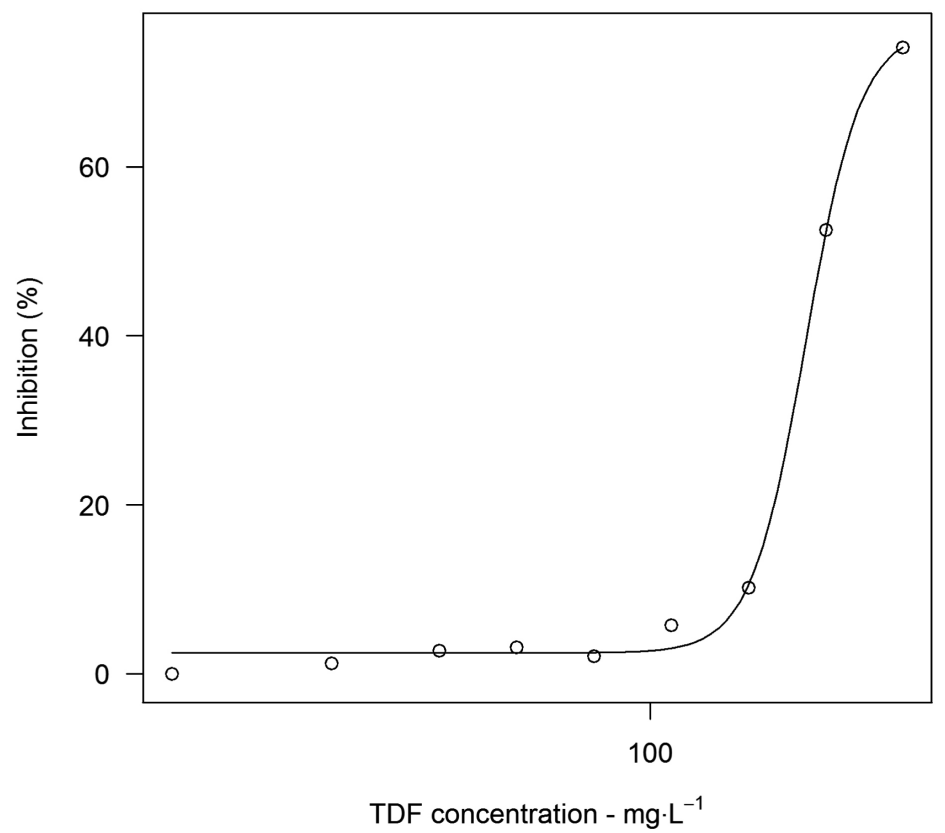

(b)

Figure 2. Growth (a) inhibition (b) curves of $M$. novacekii exposed to increasing concentrations of TDF.

Table 1. Resume of point estimates $\left(\mathrm{mg} \cdot \mathrm{L}^{-1}\right)$ of $\mathrm{IC}_{50}$ of TDF and TFV determined for the tests and species used in this study.

\begin{tabular}{ccc}
\hline Test organism & Parameters & IC $_{50}\left(\mathrm{mg} \cdot \mathrm{L}^{-1}\right)$ \\
\hline M. novacekii & TDF Growth inhibition (cell density) $96 \mathrm{~h}$ & $161.01(156.81 ; 165.21)$ \\
\multirow{2}{*}{ A. salina } & TFV & $89.00(86.67 ; 91.31)$ \\
& TDF Immobility 24 h & $111.82(103.18 ; 120.45)$ \\
A. fischeri & TFV & $61.83(57.05 ; 66.59)$ \\
& TDF Luminescence inhibition 15 min & $14.83(13.87 ; 15.79)$ \\
& TFV & $8.20(7.67 ; 8.73)$ \\
\hline
\end{tabular}


Cyanobacteria as well as bacteria possess some metabolic systems similar to those of eukaryotic cells, with most enzymatic pathways present, including esterase enzymes [33]. Therefore, the toxicity of the antiviral drug may be expressed as that of TFV, because TDF is a prodrug. The hydrolysis product (TFV) is the bioactive form of the drug binds reverse transcriptase by disrupting DNA synthesis drug [7]. Wood et al. (2015) [13] detected in the environment the active drug TFV. In this case, there is a considerable reduction in the growth inhibitory concentrations, causing the TFV to be classified as category 3, i.e., having moderate environmental toxicity. The expression of toxicity in terms of TFV is also important because TDF is de-esterified in the human body and excreted as TFV (c.a. $80 \%$ of TDF absorved) that can contaminate domestic sewage.

The results obtained in this study are similar to those reported by Russo et al. (2018) [34] for antiretroviral nucleoside analogues stavudine and zidovudine belonging the same group of TDF. According to those studies, these drugs presented a weak inhibitory activity on Raphidocelis subcapitata growth, microalga specie very used in ecotoxicological studies.

The resistance of cyanobacteria to antivirals can be explained by morphological aspects such as mucilaginous production and the presence of cell walls. The phytoplankton biomass can also act as a biosorbent for hydrophobic organic pollutants [35] [36] [37]. The extracellular polymeric substances (EPS) present in mucilaginous layer, containing functional groups such as amine, carboxyl, and phosphate [38] can provide binding sites for the biosorption of hydrophilic substances. Thus, EPS can retain xenobiotics in the mucilaginous layer, protecting the cell from toxic compounds.

\subsection{Toxicity of TDF to A. salina}

In this study, the $\mathrm{IC}_{50}$ of $\mathrm{TDF}$ for $A$. salina was lower than the estimated $\mathrm{EC}_{50}$ for $M$. novacekii. Other studies have already reported the same results in terms of the higher sensitivity of the $A$. salina model compared to a primary producer as a test organism [39] [40].

Although single-celled species are apparently more sensitive to xenobiotics, certain aspects of $A$. salina may explain its high sensitivity. A. salina is a known filtering organism that is able to bioaccumulate xenobiotics [38] [41]. This process can lead to higher intra-organism concentrations of xenobiotics than external concentrations. Furthermore, TDF may be more bioavailable in saline than in the ASM1 medium and may cross membranes, thereby increasing the concentration of the intracellular drug. We supposed that in intracellular medium, esterases of $A$. salina can hydrolyse TDF, releasing TFV.

Although the mechanism of toxicity of TFV to the crustacean $A$. salina has not been elucidated, many enzymes involved in the metabolic process of this species exhibit increased activity during larval development, including the adenosine triphosphatase activated by sodium and potassium (Na, K-ATPase) [42] [43] and hydrolases [44]. Ahmed-Ouameur et al. (2005) [45] have shown 
that AZT, another viral reverse transcriptase inhibitor, binds to Na, K-ATPase in vitro. This enzyme reaches very high levels in nauplii, and it is the main physiological mechanism of osmoregulation. Any disturbance in the activity of this enzyme can lead to organism death. It is possible that TFV may also interact with this crustacean enzyme, causing toxic effects. The elucidation of TFV toxicity mechanisms for this species was not the aim of this study, however, it is important to consider the characteristics of model organisms that may explain the sensitivity of the test.

\subsection{Toxicity of TDF to A. fischeri}

A. fischeri was very sensitive to TDF, which is an important aspect to consider. TFV has great chemical stability in the environment and is biodegraded slowly [46] [47] [48]. A. fischeri is a saprophyte bacterium, therefore, it can be proposed that TFV can potentially affect biological processes in aerobic treatment systems.

An initial increase in bioluminescence was observed in the test with $A$. fischeri. This effect has been described for several species under stress conditions and is attributed to the hormesis phenomenon, a process that stimulates the metabolism of toxic chemicals at very low concentrations. Mennillo et al. (2018) [49] investigated the ecotoxicological properties of ketoprofen, an anti-inflammatory drug and reported a hormetic effect on $A$. fischeri exposed to ketoprofen.

Although $A$. fischeri is more sensitive to TDF than the other organisms in this study, other researchers have obtained different results. Maselli et al. (2015) [50] compared the sensitivities of different ecotoxicity tests for crude and treated effluents from the pharmaceutical industry and found that the crustacean Daphnia similis and the microalga Raphidocelis subcapitata were more sensitive as indicators of toxicity than $A$. fischeri. The same observation was made by Minagh et al. (2009) [51] regarding the toxicity of sertraline to A. fischeri and Daphnia magna, with the latter being the more sensitive species.

The variation in the toxicity of a chemical compound for different test organisms species is due to differences in the interaction between the substance and the target system of each species studied, the time of exposure and the ability of the organisms to recover during and after exposure. Therefore, to evaluate environmental toxicity, the use of several test organisms is recommended because species maintain different mechanisms of resistance to xenobiotics and the use of organisms from different trophic levels may reveal a cascading effect of a chemical on the aquatic ecosystem.

Environmental studies on the impact of TFV on aquatic biota have not been described in the literature, despite the presence of the drug at low concentrations (145 - $\left.243 \mathrm{ng} \cdot \mathrm{L}^{-1}\right)$ in surface waters in South Africa [13]. It is emphasized that no risk is expected for this drug at the concentrations already detected in the environment. However, investigations about toxic effects of this drug are very im- 
portant because TDF has many uses (hepatitis, prevention of HIV infection and treatment of HIV-infected patients) and may be an environmental problem in the future. It should also be noted that TDF is a drug that inhibits DNA replication and may also act on other non-target species with serious ecological impacts.

\section{Conclusions}

According to the organism bioindicators used to estimate TDF toxicity, $A$. fischeri was the most sensitive model to the toxic effects of TDF, while $M$. novacekii (cyanobacteria) and $A$. salina (crustacean) were moderately sensitive to the drug.

This result is worrying because $A$. fischeri is saprophytic; thus, this can indicate possible injurious effects on the other decomposer organisms, possibly inhibiting drug biodegradation. TFV is a very stable molecule, and biodegradation inhibition can contribute to enhancing the persistence of this drug in the environment.

Although TDF has shown moderate toxicity to the other organisms tested, algae and crustaceans, this does not mean that the drug is environmentally safe. It is necessary to consider the stability and low solubility of TFV in aqueous medium. This drug could accumulate in the environment and bioaccumulate in aquatic organisms. In addition, it should be emphasized that active pharmaceutical compounds are normally present as mixtures in aquatic environments. In HIV treatment, TDF is mainly administered in association with other antiviral drugs. Thus, additive or potentiating toxic effects can still occur, increasing damage to the ecosystem.

The present results highlight that a battery of bioassays representing different trophic levels is fundamental in predicting the toxicity of drugs, regardless of whether significant variations can occur between species tests. Furthermore, the tests provide the information required to define safe levels of drugs for living organisms in the environment. In addition, the physicochemical properties of TFV and the toxicity to the species tested in this study indicate the need to investigate the presence of this drug on the environment, its persistence after effluent treatment and potential disturbances in the equilibrium of aquatic ecosystems.

\section{Acknowledgements}

This study was funded by the Minas Gerais State Agency for Research and Development-FAPEMIG (process n. CEX-APQ-01626-14).

The authors thank Professor Liséte Celina Lange and Dra Raquel Sampaio Jacob of the Engineering School of UFMG in their collaboration for this study.

\section{Ethical Approval}

This article does not contain any studies with human participants or vertebrate 
animals performed by any of the authors.

\section{Conflicts of Interest}

The authors declare that they have no conflict of interest.

\section{References}

[1] López-Doval, J.C., Montagner, C.C., Alburquerque, A.F., Moschini-Carlos, V., Umbuzeiro, G. and Pompêo, M. (2017) Nutrients, Emerging Pollutants and Pesticides in a Tropical Urban Reservoir: Spatial Distributions and Risk Assessment. Science of The Total Environment, 575, 1307-1324.

https://doi.org/10.1016/j.scitotenv.2016.09.210

[2] Schaider, L.A., Rudel, R.A., Ackerman, J.M., Dunagan, S.C. and Brody, J.G. (2014) Pharmaceuticals, Perfluorosurfactants, and Other Organic Wastewater Compounds in Public Drinking Water Wells in a Shallow Sand and Gravel Aquifer. Science of The Total Environment, 468-469, 384-393. https://doi.org/10.1016/j.scitotenv.2013.08.067

[3] Rimayi, C., Odusanya, D., Weiss, J.M., Boer, J. and Chimuka, L. (2018) Contaminants of Emerging Concern in the Hartbeespoort Dam Catchment and the Mngeni River Estuary 2016 Pollution Incident, South Africa. Science of The Total Environment, 627, 1008-1017. https://doi.org/10.1016/j.scitotenv.2018.01.263

[4] Godoy, A.A., Kummrow, F. and Pamplin, P.A. (2015) Occurrence, Ecotoxicological Effects and Risk Assessment of Antihypertensive Pharmaceutical Residues in the Aquatic Environment-A Review. Chemosphere, 138, 281-291. https://doi.org/10.1016/j.chemosphere.2015.06.024

[5] Agunbiade, F.O. and Moodley, B. (2016) Occurrence and Distribution Pattern of Acidic Pharmaceuticals in Surface Water, Wastewater, and Sediment of the Msunduzi River, Kwazulu-Natal, South Africa. Environmental Toxicology and Chemistry, 35, 36-46. https://doi.org/10.1002/etc.3144

[6] K'oreje, K.O., Vergeynst, L., Ombaka, D., De Wispelaere, P., Okoth, M., Van Langenhove, H. and Demeestere, K. (2016) Occurrence Patterns of Pharmaceutical Residues in Wastewater, Surface Water and Groundwater of Nairobi and Kisumu City, Kenya. Chemosphere, 149, 238-244.

https://doi.org/10.1016/j.chemosphere.2016.01.095

[7] Kearney, B.P., Flaherty, J.F. and Shah, J. (2004) Tenofovir Disoproxil Fumarate: Clinical Pharmacology and Pharmacokinetics. Clinical Pharmacokinetics, 43, 595-612. https://doi.org/10.2165/00003088-200443090-00003

[8] Kim, Y.K., Choi, M.J., Oh, T.Y., Yu, K.-S. and Lee, S. (2017) A Comparative Pharmacokinetic and Tolerability Analysis of the Novel Orotic Acid Salt form of Tenofovir Disoproxil and the Fumaric Acid Salt form in Healthy Subjects. Drug Design, Development and Therapy, 11, 3171-3177. https://doi.org/10.2147/DDDT.S149125

[9] Al-Rajab, A.J., Sabourin, L., Chapman, R., Lapen, D.R. and Topp, E. (2010) Fate of the Antiretroviral Drug Tenofovir in Agricultural Soil. Science of the Total Environment, 408, 5559-5564. https://doi.org/10.1016/j.scitotenv.2010.07.074

[10] Ncube, S., Madikizel, L.M., Chimuka, L. and Nindi, M.M. (2018) Environmental Fate and Ecotoxicological Effects of Antiretrovirals: A Current Global Status and Future Perspectives. Water Research, 145, 231-247. https://doi.org/10.1016/j.watres.2018.08.017

[11] Prasse, C., Schlüsener, M.P., Schulz, R. and Ternes, T.A. (2010) Antiviral Drugs in 
Wastewater and Surface Waters: A New Pharmaceutical Class of Environmental Relevance? Environmental Science \& Technology, 44, 1728-1735. https://doi.org/10.1021/es903216p

[12] Jain, S., Kumar, P. and Vas, R.K. (2013) Occurrence and Removal of Antiviral Drugs in Environment: A Review. Water, Air, \& Soil Pollution, 224, 1410-1413. https://doi.org/10.1007/s11270-012-1410-3

[13] Wood, T.P., Duvenage, C.S.J. and Rohwer, E. (2015) The Occurrence of Anti-Retroviral Compounds Used for HIV Treatment in South African Surface Water. Environmental Pollution, 199, 235-243. https://doi.org/10.1016/j.envpol.2015.01.030

[14] Taylor, D. and Senac, T. (2014) Human Pharmaceutical Products in the Environment-the "Problem" in Perspective. Chemosphere, 115, 95-99.

https://doi.org/10.1016/j.chemosphere.2014.01.011

[15] Ghosh, P., Thakur, I.S. and Kaushik, A. (2017) Bioassays for Toxicological Risk Assessment of Landfill Leachate: A Review. Ecotoxicology and Environmental Safety, 141, 259-270. https://doi.org/10.1016/j.ecoenv.2017.03.023

[16] El-Bestawy, E.A., Ab El-salam, A.L. and Mansy, A.E.R. (2007) Potential Use of Environmental Cyanobacterial Species in Bioremediation of Lindane-Contaminated Effluents. International Biodeterioration \& Biodegradation, 59, 180-192. https://doi.org/10.1016/j.ibiod.2006.12.005

[17] Bukaveckas, P.A., Franklin, R., Tassone, S., Trache, B. and Egerton, T. (2018) Cyanobacteria and Cyanotoxins at the River-Estuarine Transition. Harmful Algae, 76, 11-21. https://doi.org/10.1016/j.hal.2018.04.012

[18] Bicudo, C. and Menezes, M. (2006) Gêneros de algas continentais do Brasil: chave para identificação e descrições. RiMa, São Carlos.

[19] Ates, M., Demir, V., Arslan, Z., Camas, M. and Celik, F. (2016) Toxicity of Engineered Nickel Oxide and Cobalt Oxide Nanoparticles to Artemia salina in Seawater. Water, Air, \& Soil Pollution, 227, 70-78. https://doi.org/10.1007/s11270-016-2771-9

[20] Rajabi, S., Ramazani, A., Hamid, M. and Naji, T. (2015) Artemia salina as a Model Organism in Toxicity Assessment of Nanoparticles. DARU Journal of Pharmaceutical Sciences, 23, 20. https://doi.org/10.1186/s40199-015-0105-X

[21] Abbas, M., Adil, M., Ehtisham-Ul-Haque, S., Munir, B., Yameen, M., Ghaffar, A., Shar, G.A., Asif Tahir, M. and Iqbal, M. (2018) Vibrio Fischeri Bioluminescence Inhibition Assay for Ecotoxicity Assessment: A Review. Science of the Total Environment, 626, 1295-1309. https://doi.org/10.1016/j.scitotenv.2018.01.066

[22] Fioravante, I.A., Albergaria, B., Teodoro, T.S., Starling, S.M., Barbosa, F. and Augusti, R. (2012) Removal of $17 \alpha$-Ethinylestradiol from a Sterile WC Medium by the Cyanobacteria Microcystis novacekii. Journal of Environmental Monitoring, 14, 2362-2366. https://doi.org/10.1039/c2em30320e

[23] Gorham, P.R., McLachlan, J., Hammer, U.T. and Kim, W.K. (1964) Isolation and Culture of Toxic Strains of Anabaena Flos-Aquae (Lyngb.) de Bréb. SIL Proceedings, 15, 796-804. https://doi.org/10.1080/03680770.1962.11895606

[24] Ma, J., Lin, F., Qin, W. and Wang, P. (2004) Differential Response of Four Cyanobacterial and Green Algal Species to Triazophos, Fentin Acetate, and Ethephon. Bulletin of Environmental Contamination and Toxicology, 73, 890-897. https://doi.org/10.1007/s00128-004-0510-1

[25] OECD (2006) Freshwater Alga and Cyanobacteria, Growth Inhibition Test. Organization for Economic Cooperation and Development-Guidelines for Testing 
Chemicals.

[26] Meyer, B.N., Ferrigni, N.R., Putnam, J.E., Jacobsen, L.B., Nichols, D.E. and Mclaughlin, J.L. (1982) Brine Shrimp: A Convenient General Bioassay for Active Plant Constituents. Planta Medica, 45, 31-34. https://doi.org/10.1055/s-2007-971236

[27] Associação Brasileira de Normas Técnicas (ABNT) (2012) NBR 15411-3: Ecotoxicologia Aquática-Determinação do efeito inibitório de amostras de água sobre a emissão de luz de Vibrio fischeri (ensaio de bactéria luminescente). Rio de Janeiro, $23 \mathrm{p}$.

[28] Oller, I., Gernjak, W., Maldonado, M.I., Pérez-Estrada, L.A., Sánchez-Pérez, J.A. and Malato, S. (2006) Solar Photocatalytic Degradation of Some Hazardous Water-Soluble Pesticides at Pilot-Plant Scale. Journal of Hazardous Materials, 138, 507-517. https://doi.org/10.1016/j.jhazmat.2006.05.075

[29] Ritz, C., Baty, F., Streibig, J.C. and Gerhard, D. (2015) Dose-Response Analysis Using R. PLoS ONE, 10, e0146021. https://doi.org/10.1371/journal.pone.0146021

[30] Yuan, L., Dahl, T.C. and Oliyai, R. (2001) Degradation Kinetics of Oxycarbonyloxymethyl Prodrugs of Phosphonates in Solution. Pharmaceutical Research, 18, 234-237. https://doi.org/10.1023/A:1011044804823

[31] Brooks, K.M., Ibrahim, M.E., Castillo-Mancilla, J.R., MaWhinney, S., Alexander, K., Tilden, S., Kerr, B., Ellison, L., McHugh, C., Bushman, L.R., Kiser, J., Hosek, S., Huhn, G.D. and Anderson, P.L. (2019) Pharmacokinetics of Tenofovir Monoester and Association with Intracellular Tenofovir Diphosphate Following Single-Dose Tenofovir Disoproxil Fumarate. Journal of Antimicrobial Chemotherapy, 74, 2352-2359. https://doi.org/10.1093/jac/dkz187

[32] GHS (2017) Globally Harmonized System of Classification and Labelling of Chemicals. United Nations, New York.

[33] Panda, T. and Gowrishankar, B.S. (2005) Production and Applications of Esterases. Applied Microbiology and Biotechnology, 67, 160-169.

https://doi.org/10.1007/s00253-004-1840-y

[34] Russo, D., Siciliano, A., Guida, M., Andreozzi, R., Reis, N.M., Li, Puma, G.L. and Marotta, R. (2018) Removal of Antiretroviral Drugs Stavudine and Zidovudine in Water under $\mathrm{UV}_{254}$ and $\mathrm{UV}_{254} / \mathrm{H}_{2} \mathrm{O}_{2}$ Processes: Quantum Yields, Kinetics and Ecotoxicology Assessment. Journal of Hazardous Materials, 349, 195-204. https://doi.org/10.1016/j.jhazmat.2018.01.052

[35] Gao, J.F., Zhang, Q., Wang, J.H., Wu, X.L., Wang, S.Y. and Peng, Y.Z. (2011) Contributions of Functional Groups and Extracellular Polymeric Substances on the Biosorption of Dyes by Aerobic Granules. Bioresource Technology, 102, 805-813. https://doi.org/10.1016/j.biortech.2010.08.119

[36] Wang, Z., Hessler, C.M., Xue, Z. and Seo, Y. (2012) The Role of Extracellular Polymeric Substances on the Sorption of Natural Organic Matter. Water Research, 46, 1052-1060. https://doi.org/10.1016/j.watres.2011.11.077

[37] Bai, L., Xu, H., Wang, C., Deng, J. and Jiang, H. (2016) Extracellular Polymeric Substances Facilitate the Biosorption of Phenanthrene on Cyanobacteria Microcystis aeruginosa. Chemosphere, 162, 172-180. https://doi.org/10.1016/j.chemosphere.2016.07.063

[38] More, T.T., Yadav, J.S., Yan, S., Tyagi, R.D. and Surampalli, R.Y. (2014) Extracellular Polymeric Substances of Bacteria and Their Potential Environmental Applications. Journal of Environmental Management, 144, 1-25. https://doi.org/10.1016/j.jenvman.2014.05.010

[39] Oliveira-Filho, E.C. and Paumgartten, F.J. (2000) Toxicity of Euphorbia milii Latex and Niclosamidetosnails and Nontarget Aquatic Species. Ecotoxicology and Envi- 
ronmental Safety, 46, 342-350. https://doi.org/10.1006/eesa.2000.1924

[40] Bhuvaneshwari, M., Thiagarajan, V., Nemade, P., Chandrasekaran, N. and Mukherjee, A. (2018) Toxicity and Trophic Transfer of $\mathrm{P}_{2} 5 \mathrm{TiO}_{2} \mathrm{NPs}$ from Dunaliella salina to Artemia salina: Effect of Dietary and Waterborne Exposure. Environmental Research, 160, 39-46. https://doi.org/10.1016/j.envres.2017.09.022

[41] Riisgard, H.U., Jeune, N., Pleissner, D., Zalacáin, D., Lüskow, F. and Wiersma, J.B. (2015) Adaptation of the Brine Shrimp Artemia salina (Branchiopoda: Anostraca) to Filter-Feeding: Effects of Body Size and Temperature on Filtration and Respiration Rates. Journal of Crustacean Biology, 35, 650-658. https://doi.org/10.1163/1937240X-00002362

[42] Fisher, J.A., Baxter-Lowe, L.A. and Hokin, L.E., (1986) Regulation of Na, K-ATPase Biosynthesis in Developing Artemia salina. The Journal of Biological Chemistry, 261, 515-519.

[43] Peterson, G.L., Ewing, R.D. and Conte, F.P. (1978) Membrane Differentiation and de Novo Synthesis of the $\left(\mathrm{Na}^{+}+\mathrm{K}^{+}\right)$-Activated Adenosine Triphosphatase during Development of Artemia salina Nauplii. Developmental Biology, 67, 90-98. https://doi.org/10.1016/0012-1606(78)90302-0

[44] Miralles, J., Sebastian, J. and Heredia, C.F. (1978) Independent Temporal Expression of Two N-Substituted Aminoacyl-tRNA Hydrolases during the Development of Artemia salina. Biochimica et Biophysica Acta, 518, 326-333. https://doi.org/10.1016/0005-2787(78)90189-2

[45] Ahmed-Ouameur, A., Neault, J.F., Claveau, S. and Tajmir-Riahi, H.A. (2005) AZT binding to Na, K-ATPase. Cell Biochemistry and Biophysics, 42, 87-94. https://doi.org/10.1385/CBB:42:1:087

[46] Havele, S. and Dhaneshwar, S.R. (2012) Development and Validation of a Stability-Indicating Lc Method for the Determination of Tenofovir Disoproxil Fumarate in Pharmaceutical Formulation. Songklanakarin Journal of Science and Technology, 34, 615-622. https://doi.org/10.1100/2012/894136

[47] Shashi Kumar, B.M. and Rajkamal, B. (2017) A Simple, Selective, Rapid and Rugged Method Development and Validation of Tenofovir and Rilpivirine in Human Plasma Using Liquid Chromatography Coupled with Tandem Mass Spectrometry. European Journal of Pharmaceutical and Medical Research, 4, 605-613.

[48] Agrahari, V., Putty, S., Mathes, C., Murowchick, J.B. and Youan, B.B.C. (2014) Evaluation of Degradation Kinetics and Physicochemical Stability of Tenofovir. Drug Testing and Analysis, 7, 207-213. https://doi.org/10.1002/dta.1656

[49] Mennillo, E., Arukwe, A., Monni G., Meucci, V., Intorre, L. and Pretti, C. (2018) Ecotoxicological Properties of Ketoprofen and the $\mathrm{S}^{+}$-Enantiomer (Dexketoprofen): Bioassays in Freshwater Model Species and Biomarkers in Fish PLHC-1 Cell Line. Environmental Toxicology and Chemistry, 37, 201-212. https://doi.org/10.1002/etc.3943

[50] Maselli, B.S., Luna, L.A., Palmeira, J.O., Tavares, K.P., Barbosa, S., Beijo, L.A., Umbuzeiro, G.A. and Kummrow, F. (2015) Ecotoxicity of Raw and Treated Effluents Generated by a Veterinary Pharmaceutical Company: A Comparison of the Sensitivities of Different Standardized Tests. Ecotoxicology, 24, 795-804.

https://doi.org/10.1007/s10646-015-1425-9

[51] Minagh, E., Hernan, R., O’Rourke, K., Lyng, F.M. and Davoren, M. (2009) Aquatic Ecotoxicity of the Selective Serotonin Reuptake Inhibitor Sertraline Hydrochloride in a Battery of Freshwater Test Species. Ecotoxicology and Environmental Safety, 72, 434-444. https://doi.org/10.1016/j.ecoenv.2008.05.002 